\title{
15. FLUCTUATION IN EOLIAN SEDIMENTATION DURING THE PAST FIVE GLACIAL-INTERGLACIAL CYCLES: A PRELIMINARY EXAMINATION OF DATA FROM DEEP SEA DRILLING PROJECT HOLE 503B, EASTERN EQUATORIAL PACIFIC ${ }^{1}$
}

\author{
David K. Rea, Department of Atmospheric and Oceanic Science, University of Michigan, Ann Arbor, Michigan
}

\begin{abstract}
Pelagic sediments from DSDP Hole 503B contain, in their carbonate abundance data, a clear record of glacialinterglacial cycles. The eolian component of those sediments was analyzed over the past four carbonate cycles, and the mass accumulation rate (MAR) and grain size of the eolian component was determined. Eolian MARs range from 24 to $169 \mathrm{mg} / \mathrm{cm}^{2} / 10^{3} \mathrm{y}$. and commonly are higher by a factor of three to five during times of glacial retreat. Reduced contribution during periods of glaciation most likely reflects glacial-age humidity in the American source. Grain-size values $\left(\phi_{50}\right)$ range from 8.25 to a minimum of $8.79 \phi-$ a variation in grain mass by a factor of 3.1. Larger grains reflect more vigorous atmospheric circulation, but sizes do not covary with the carbonate or eolian accumulation curves. These data suggest that the intensity of atmospheric circulation in the tropics may reflect the $42,000 \mathrm{y}$.-tilt cycle rather than the 100,000 y.-cycle of glacial advance.
\end{abstract}

\section{EOLIAN SEDIMENTATION}

Eolian debris is the only component of deep-sea sediment providing direct information about the atmospheric circulation patterns and changes in wind intensity that influenced past oceanic surface-water circulation. To date, most estimates of atmospheric circulation have been indirect and based on inferred changes of upwelling intensity as recorded by the preservation in biogenic opal (Pisias, 1976; Molina-Cruz, 1977; Leinen, 1979). Sophisticated models of atmospheric circulation during a glaciation (Gates, 1976; Manabe and Hahn, 1977) have been constructed from sea-surface temperatures and other climatic indicators for the last major ice advance, 18,000 y. ago (CLIMAP, 1976).

In the simplest case, the vigor of the global wind systems should depend directly on the pole-to-equator temperature gradient. As this gradient becomes more or less intense, the wind intensity should wax or wane. The accumulation of eolian sediment is also controlled by the climate (actually, vegetative cover) of the source; more arid regions provide larger quantities of dust.

More than a decade ago, Windom (1969) suggested that as much as $75 \%$ of the nonbiogenic component of deep-sea sediment was atmospheric dust fallout. Recent estimates of this contribution of continental dust to the world's oceans are in the range of 0.5 to $1.0 \times 10^{15} \mathrm{~g} / \mathrm{y}$. (Savoie and Prospero, 1980), corresponding to an average mass flux to the ocean floor of about 150 to $300 \mathrm{mg} /$ $\mathrm{cm}^{2} / 10^{3} \mathrm{y}$. Particulate accumulation in snowfields is of a similar order of magnitude, although generally less than $100 \mathrm{mg} / \mathrm{cm}^{2} / 10^{3} \mathrm{y}$. (Windom, 1969). Eolian contributions to surface sediment commonly have been estimated by the concentration of quartz (Rex and Goldberg, 1958). Patterns of prevailing winds are reflected in decreasing quartz concentrations away from the conti-

\footnotetext{
${ }^{1}$ Prell, W. L., Gardner, J. V., et al., Init. Repts. DSDP, 68: Washington (U.S. Govt. Printing Office),
}

nental source (Lisitzin, 1972; Windom, 1975; MolinaCruz and Price, 1977; Thiede, 1979; Johnson, 1979; Leinen and Heath, 1981). In some cases, illite and kaolinite concentrations in surface sediment also reflect eolian transport (Windom, 1975).

There have been relatively few downcore studies of eolian materials. Parkin and his coworkers (Parkin, 1974; Parkin and Shackleton, 1973; Parkin and Padgham, 1975) studied two cores from the northwest African continental margin and found that both the abundance and size of quartz grains larger than $7 \mu \mathrm{m}$ increased during glacial times, implying stronger northeast tradewinds. Thiede (1979) has shown that the region of high quartz concentration east of Australia and New Zealand was much more extensive during the last glaciation than it is now, implying either that the Southern Hemisphere westerlies were stronger during glacial times, or that Australia was more arid.

Molina-Cruz $(1975,1977)$ analyzed quartz content and other data from two cores recovered near the South American continent $\left(3.6^{\circ} \mathrm{S}\right.$ and $\left.16.4^{\circ} \mathrm{S}\right)$. Both cores showed fluctuations in the quartz accumulation rate of a factor of two; larger values usually coincided with higher $\mathrm{CaCO}_{3}$ accumulation rates. Both cores, however, have total mineral mass accumulation rates (MAR) of 500 to $2000 \mathrm{mg} / \mathrm{cm}^{2} / 10^{3} \mathrm{y}$. (Molina-Cruz, 1975)-rates normally indicating hemipelagic deposition. It is, therefore, not clear that the nonbiogenic component of those cores records a predominantly eolian signal. Multivariate statistical analysis of all data from the core at $3.6^{\circ} \mathrm{S}$, $83.9^{\circ} \mathrm{W}, \mathrm{V} 19-29$, led Molina-Cruz (1977) to suggest that the speed of the southeast tradewinds increased by 30 to $50 \%$ from interglacial to glacial times. The pattern of opal productivity is not as clear: Preservation of opal in the eastern equatorial Pacific may have been greater during interglacials (Molina-Cruz, 1977; Mikkelsen, 1978).

I have studied longer-term changes, which range back to the Middle Cretaceous, in the wind-borne component of North Pacific pelagic sediment (Rea and Janecek, 
1980; Janecek et al., 1980; Rea and Janecek, in press a; Rea and Harrsch, in press; Rea and Janecek, in press b). Our data include eolian MAR, which we interpret in terms of source-area climate or supply, and eolian grain size, which we interpret in terms of wind intensity. These studies indicate that a large change in the grain size of eolian sediment occurred about $3 \mathrm{Ma}$ in conjunction with the onset of Northern Hemispheric glaciation; it is recorded as a 5 - to 10 -fold increase in the accumulation of eolian sediments and a doubling of the mass of the average wind-borne grain. In this study I have examined the eolian fraction of Pleistocene sediment to determine and quantify changes in atmospheric circulation during the glacial-interglacial cycles.

\section{METHODS}

The basic datum is the weight percentage of the total eolian load rather than only the weight percentage of quartz, which may be only 20 to $30 \%$ - or even less (Windom, 1969; Prospero and Bonatti, 1969; Johnson, 1979; Prospero and others, 1981) of the wind-transported sediment and the grain size of the total eolian component. I isolated the eolian fraction by a series of extractions to remove $\mathrm{CaCO}_{3}$, opaline silica, $\mathrm{Fe}$ and $\mathrm{Mn}$ oxides and hydroxides, and zeolites. Authigenic clays and feldspars would survive this procedure, but photographs taken with a scanning electron microscope during various stages of the extraction and the general coherency of the data suggest that they do not present a major problem, especially in these geologically young sediments. If the sample site is far from land, on a topographic elevation, or otherwise protected from downslope hemipelagic transport, the nonauthigenic, inorganic sedimentary component isolated by our technique presumably represents eolian material. The grain size of the $>1.0-\mu \mathrm{m}$ fraction of the eolian component was determined by Coulter counter at $0.5 \phi$ intervals, and the median grain size was determined (Folk, 1974). Resulting data have a precision of $\pm 5 \%$ for the weightpercentage values and \pm 0.05 to $0.10 \phi$ for grain size. A detailed description of the laboratory procedures has been given by Rea and Janecek (in press a).

\section{OCEANOGRAPHIC AND PALEOCLIMATIC SETTING}

Hydraulic Piston Cores 503B-1 and 503B-2 contain Pleistocene to Holocene siliceous carbonate ooze, alternating from white to light tan (see site chapter, this volume). The site lies north of the Galapagos spreading center and east of the East Pacific Rise at $4^{\circ} 03.0^{\prime} \mathrm{N} ; 95^{\circ}$ $38.3^{\prime} \mathrm{W}$, in 3672 meters of water. It is between the zones of maximum influence of the northeast and southeast tradewinds (Molina-Cruz, 1977). Eolian materials should therefore have a Central American or perhaps northern South American source, depending on the position of the tradewinds.

During the last glacial maximum, sea-surface temperatures in the area were similar to modern temperatures (CLIMAP, 1976; Moore et al., 1980). Climatic modeling suggests that the intensity of the tradewinds was about $20 \%$ greater during glacial times (Gates, 1976). Molina-Cruz's (1977) estimate of tradewind strength, based on quartz content of sediments, suggests that wind intensities may have increased by 30 to $50 \%$. Climatic conditions in the eolian source area during glacial times are somewhat more problematical. Most of the temperate and tropical world was more arid during the height of the last glaciation, 18,000 y. ago (Williams, 1975; Gates, 1976; Manabe and Hahn, 1977; Sarnthein, 1978;
Peterson et al., 1979). It is unclear, however, whether that relative aridity persisted throughout the entire glacial cycle. Pollen from a bog suggests that the last glacial was more arid than present in tropical Australia (Kershaw, 1978), but temperate Australia may have been more moist (Bowler et al., 1976; Webster and Streten, 1978). The record of the African lakes is one of late glacial aridity, but moister conditions occurred throughout much of early and middle Wisconsinan time (Butzer et al., 1972; Frenzel, 1973; Lamb, 1977; Street and Grove, 1979). Northwest Africa may have been wetter during glacial time (Diester-Haass, 1976). In the southwestern United States, there may also have been increased soil moisture and vegetative cover during glacial times (Brakenridge, 1978). The climatic record of northwestern South America is ambiguous, but the Chilean Andes were apparently wetter during glaciations (Peterson et al., 1979).

None of the studies of the Wisconsinian climate address Central America specifically. If that region were more humid during glaciations, then one would expect a reduced contribution of eolian materials during glacial times. Alternatively, a more arid climate should result in an increased eolian component in marine sediments downwind from the source. Stronger winds during the glacial ages should bring larger grains to the site of deposition-indeed, the history of wind velocity should be recorded in the grain-size curves of the eolian materials.

Sediments from Hole 503B may provide an unequivocal record of atmospheric activity during the late Pleistocene glacial-interglacial intervals. The apparently eolian records in the cores studied by Parkin (1974) and by Molina-Cruz $(1975,1977)$ seem almost certainly complicated by the downslope or hemipelagic transport of terrigenous materials (Parkin's cores were raised from the lower continental slope off Northwest Africa). The excellent record of carbonate fluctuations (Fig. 1 and Gardner, this volume), will allow comparison of the data and an estimation of synchroneity or lags between the $\mathrm{CaCO}_{3}$ and eolian maxima and minima. When oxygen isotope stratigraphy for this core is complete, the eolian record will be directly correlatable with the glacial ice-volume record.

\section{DATA}

\section{Calcium Carbonate}

Fluctuations in the carbonate content of Pacific sediments were first recognized by Arrhenius (1952), who correlated the carbonate-rich intervals with glacial stages. $\mathrm{He}$ considered higher carbonate values to be the result of increased surface-water productivity. Arrhenius (1952) assigned successive even numbers to the carbonate peaks. Hays and others (1969) further defined the equatorial Pacific carbonate cycles and assigned successive odd numbers to the minima, with a B (for Bruhnes) prefix. The Hole 503B sediments, then, contain Glacial Carbonate Maxima 2, 4, 6, and 8 and Interglacial Minima B-3, B-5, B-7, and B-9. The record at this site appears to be of unusually high quality (Fig. 1 and Gardner, this volume). Fluctuations in $\mathrm{CaCO}_{3}$ percentages 


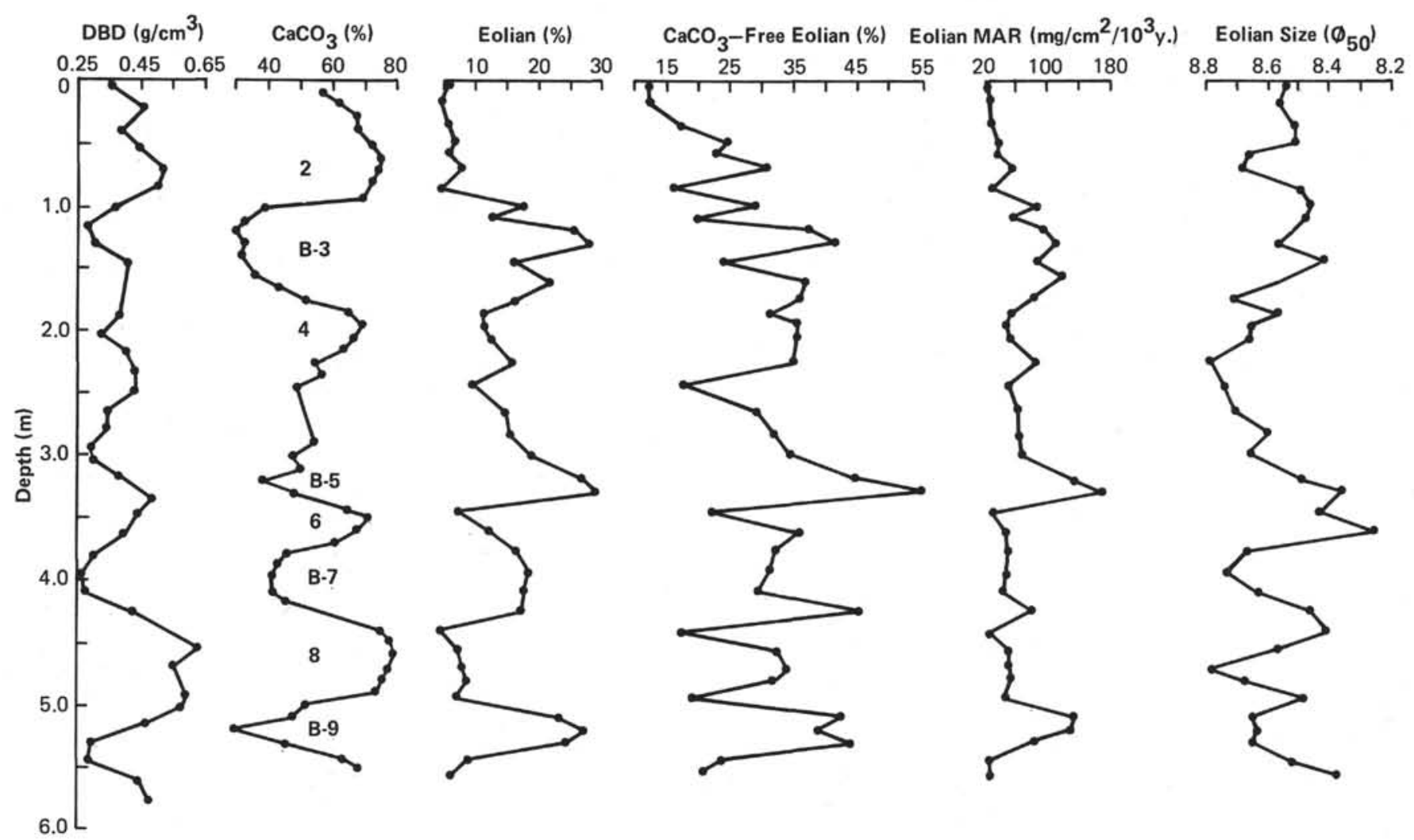

Figure 1. Eolian and other data from Hole 503B, Cores 1 and 2. (Dry-bulk density calculated from Mayer's data [this volume]; weight-percentage $\mathrm{CaCO}_{3}$ data from Gardner [this volume] with carbonate stage numbers; weight-percentage of eolian material; weight-percentage eolian material on a carbonate-free basis; MAR of the eolian material; grain size [ $\phi_{50}$ of Folk, 1974] of the eolian material.)

are now considered to reflect changing amounts or rates of dissolution (Hays et al., 1969; Thompson and Saito, 1974), with less dissolution during glacial times.

The percentage of calcium carbonate within the sediments fluctuates in the uppermost portion of Hole 503B by about a factor of two (Table 1; Fig. 1; data from Gardner, this volume). Four carbonate maxima containing 68 to $79 \% \mathrm{CaCO}_{3}$ and four minima of 29 to $40 \%$ occur in the top 5.5 meters of sediment. An expected surficial low representing the present interglacial was either absent or not recovered (Fig. 1).

\section{Linear Sedimentation Rate}

The carbonate cycles provide a basis for determining an accurate linear sedimentation rate (LSR) for the uppermost portion of Hole 503B. Pacific carbonate cycles have not been dated directly, but they can be correlated to the $\delta^{18} \mathrm{O}$ fluctuations that have been dated (Shackleton and Opdyke, 1976). In making such a correlation it is important to note that Interglacial Stage 3 of the ${ }^{18} \mathrm{O}$ record (Emiliani, 1966) is not seen in the Pacific carbonate record, and thus Interglacial 5 from the $\delta^{18} \mathrm{O}$ records correlates with Pacific Carbonate Minimum B3 (Hays et al., 1969). This offset between isotopic stages and carbonate stages was incorporated into the stratigraphic analysis of West Pacific Cores V28-238 and V28239 by Shackleton and Opdyke $(1973,1976)$, who determined ages of the isotopic, or glacial, stage boundaries from the data derived from these cores. The ends of glaciations (terminations) are much more abrupt than their onset and therefore should result in sharper boundaries in the sedimentary record. Hole 503B contains four transitions between carbonate stages that correspond to Glacial Terminations II (Carbonate B3/4), III (B5/6), IV (B7/8) and V (B9/10), which have been assigned ages of $128,251,347$, and $440 \mathrm{ky}$., respectively (Shackleton and Opdyke, 1976).

Several investigators have found the equatorial $\mathrm{Pa}$ cific carbonate cycles to be consistently offset from the $\delta^{18} \mathrm{O}$ fluctuations. The maxima and minima in $\mathrm{CaCO}_{3}$ curves are 5000 to $10,000 \mathrm{y}$. younger than the corresponding points on the ${ }^{18} \mathrm{O}$ curves (Ninkovich and Shackleton, 1975; Pisias, 1976; Shackleton and Opdyke, 1976; Moore and others, 1977). Concurring with these authors, I here assume that this time lag does not change. The time spans between successive glacial terminations can therefore be used to generate valid linear sedimentation rates between equivalent points on the $\mathrm{CaCO}_{3}$ curve. The only error in such a scheme may be that the uppermost rate calculated, (zero to Termination II) might be somewhat low, because the actual $\mathrm{CaCO}_{3}$ change would be younger than Termination II.

Linear sedimentation rates determined in this manner are presented in Table 2. To be consistent, the $50 \%$ $\mathrm{CaCO}_{3}$ level was designated arbitrarily as the point of transition between the ending glacial regime and the following interglacial. Resulting LSR values are reasonably uniform and vary from 1 to $1.3 \mathrm{~cm} / 10^{3} \mathrm{y}$. (Table 2). 
Table $1 . \mathrm{CaCO}_{3}$ weight percentage of sediments, Cores 503B-1 and 503B-

\begin{tabular}{|c|c|c|}
\hline $\begin{array}{l}\text { Core/Section } \\
\text { (level in } \mathrm{cm} \text { ) }\end{array}$ & $\begin{array}{l}\text { Sub-bottom } \\
\text { Depth } \\
\text { (cm) }\end{array}$ & $\begin{array}{l}\mathrm{CaCO}_{3} \\
\text { (wt.\%) }\end{array}$ \\
\hline $1-1,10$ & 8 & 56.6 \\
\hline $1-1,20$ & 18 & 62.6 \\
\hline $1-1,30$ & 28 & 67.6 \\
\hline $1-1,40$ & 38 & 67.9 \\
\hline $1-1,50$ & 48 & 72.0 \\
\hline $1-1,60$ & 58 & 75.0 \\
\hline $1-1,70$ & 68 & 74.5 \\
\hline $1-1,80$ & 78 & 71.2 \\
\hline $1-1,90$ & 88 & 69.3 \\
\hline $1-1,100$ & 98 & 39.8 \\
\hline $1-1,110$ & 108 & 34.2 \\
\hline $1-1,120$ & 118 & 31.0 \\
\hline $1-1,130$ & 128 & 32.9 \\
\hline $1-1,140$ & 138 & 32.1 \\
\hline $1-2,6$ & 154 & 35.5 \\
\hline $1-2,16$ & 164 & 43.5 \\
\hline $1-2,26$ & 174 & 52.6 \\
\hline $1-2,36$ & 184 & 64.9 \\
\hline $1-2,46$ & 194 & 68.2 \\
\hline $1-2,56$ & 204 & 66.0 \\
\hline $1-2,66$ & 214 & 63.1 \\
\hline $1-2,76$ & 224 & 54.1 \\
\hline $1-2,86$ & 234 & 56.5 \\
\hline $1-2,96$ & 244 & 48.2 \\
\hline $2-1,10$ & 288 & 53.6 \\
\hline $2-1,20$ & 298 & 46.5 \\
\hline $2-1,30$ & 308 & 50.0 \\
\hline $2-1,40$ & 318 & 37.9 \\
\hline $2-1,50$ & 328 & 47.3 \\
\hline $2-1,60$ & 338 & 64.6 \\
\hline $2-1,70$ & 348 & 70.1 \\
\hline $2-1,80$ & 358 & 67.0 \\
\hline $2-1,90$ & 368 & 60.1 \\
\hline $2-1,100$ & 378 & 45.6 \\
\hline $2-1,110$ & 388 & 41.8 \\
\hline $2-1,120$ & 398 & 40.6 \\
\hline $2-1,130$ & 408 & 40.4 \\
\hline $2-1,140$ & 418 & 45.0 \\
\hline $2-2,10$ & 439 & 74.8 \\
\hline $2-2,20$ & 449 & 77.2 \\
\hline $2-2,30$ & 459 & 78.7 \\
\hline $2-2,40$ & 469 & 77.6 \\
\hline $2-2,50$ & 479 & 75.0 \\
\hline $2-2,60$ & 489 & 73.3 \\
\hline $2-2,70$ & 499 & 51.7 \\
\hline $2-2,80$ & 509 & 46.8 \\
\hline $2-2,90$ & 519 & 29.2 \\
\hline $2-2,100$ & 529 & 45.3 \\
\hline $2-2,110$ & 539 & 62.6 \\
\hline $2-2,120$ & 549 & 67.4 \\
\hline
\end{tabular}

Note: Data from Gardner (this volume).

Table 2. Determination of linear sedimentation rates (in $\mathrm{cm} /$ $10^{3} \mathrm{y}$.) from spacing of carbonate peaks, Hole 503B.

\begin{tabular}{lcrrr}
\hline $\begin{array}{c}\text { Glacial-Stage } \\
\text { Boundary } \\
\text { (termination) }\end{array}$ & $\begin{array}{c}\mathrm{CaCO}_{3} \text {-Stage } \\
\begin{array}{c}\text { Boundary } \\
\left(50 \% \mathrm{CaCO}_{3}\right)\end{array}\end{array}$ & $\begin{array}{c}\text { Depth } \\
(\mathrm{cm})\end{array}$ & $\begin{array}{c}\text { Age } \\
(\mathrm{k} . \mathrm{y} .)\end{array}$ & $\begin{array}{c}\text { LSR of } \\
\text { Interval } \\
\left(\mathrm{cm} / 10^{3} \text { y. }\right)\end{array}$ \\
\hline surface & surface & 0 & 0 & \\
5/6, T-II & B3/4 & 171 & 128 & 1.34 \\
7/8, T-III & B5/6 & 330 & 251 & 1.28 \\
9/10, T-IV & B7/8 & 422 & 347 & 0.96 \\
11/12, T-V & B9/10 & 532 & 440 & 1.18 \\
\hline
\end{tabular}

\section{Bulk Density}

To calculate the mass accumulation rate (MAR) of any sedimentary unit, the actual dry mass of sediment per unit volume, or dry-bulk density (DBD), must be determined. Then the MAR $\left(\mathrm{g} / \mathrm{cm}^{2} / 10^{3} \mathrm{y}\right.$.) is the product of the LSR $\left(\mathrm{cm} / 10^{3} \mathrm{y}\right.$.) and DBD $\left(\mathrm{g} / \mathrm{cm}^{3}\right)$. The DBD is most precisely determined by weighing, freeze drying, and reweighing a known volume of the original sample (Rea and Janecek, in press a). Accurate values also can be obtained from shipboard determinations of wet-bulk density (WBD) using the GRAPE (Gamma-Ray Attenuation Porosity Evaluator) data. Wet-bulk density values for Hole 503B sediments, determined by Mayer (this volume) can be converted to DBD values if the density of the pore water and of the sediment grains are known. Assuming a seawater density of $1.03 \mathrm{~g} / \mathrm{cm}^{3}$ and a grain density of $2.60 \mathrm{~g} / \mathrm{cm}^{3}$ (average of four values from Cores 503B-1 and 503B-2; determined from shipboard data), the conversion factor is as follows:

$$
\mathrm{DBD}=1.656 \times \mathrm{WBD}-1.706 .
$$

Table 3 contains DBD values converted from the GRAPE-WBD data of Mayer (this volume). A plot of these values (Fig. 1) shows that DBD generally covaries with the carbonate content of the sediment.

\section{Eolian Sediment: Amount and Accumulation}

The eolian component of the Hole 503B ooze was isolated by the sequential extraction procedure already mentioned and detailed by Rea and Janecek (in press a). Eolian material composes about 5 to $15 \%$ of the total sediment in $\mathrm{CaCO}_{3}$ maxima and 20 to $30 \%$ of the sediment in $\mathrm{CaCO}_{3}$ minima (Table 4; Fig. 1).

Any secondary sedimentary component should show abundance fluctuations antithetical to those of a predominant component, so the low- $\mathrm{CaCO}_{3}$, high-eolian correspondence was not unexpected. To remove the effect of the carbonate variability, the amount of eolian material was also calculated on a carbonate-free basis. Results were similar: Glacial-age sediment still contained less eolian material than did the interglacial sediment (Table 4; Fig. 1).

Mass accumulation rates of the eolian material were calculated by obtaining the product DBD $\left(\mathrm{g} / \mathrm{cm}^{3}\right) \times$ LSR $\left(\mathrm{cm} / 10^{3}\right.$ y. $) \times$ wt. $\%$ eolian component $\times 1000=$ eolian MAR (mg $/ \mathrm{cm}^{2} / 10^{3}$ y.). Eolian MARs vary by nearly an order of magnitude-from 24 to $169 \mathrm{mg} / \mathrm{cm}^{2}$ / $10^{3}$ y. (Fig. 1; Table 4). Lower values, generally $>60$ $\mathrm{mg} / \mathrm{cm}^{2} / 10^{3}$ y., are associated with High-Carbonate Stages 2, 4, 6, and 8 . Higher values are associated with Dissolution Stages B-3, B-5, and B-9. Eolian MAR values from Stage B-7 may or may not fit this pattern (Fig. 1). Lower eolian MARs during glacial times are contrary to the general trend of higher aridity during glacials and suggest a more moist source region in the American tropics and subtropics during glacial times.

\section{Eolian Sediment: Grain Size}

The size of eolian grains ranges from 8.79 to a maximum of $8.25 \phi$ (Table 4). At a constant grain density, 
Table 3. Bulk density of sediments, Hole 503B.

\begin{tabular}{crrr}
\hline Core/Section & $\begin{array}{c}\text { Sub-bottom } \\
\text { Depth } \\
\text { (cm) }\end{array}$ & $\begin{array}{c}\text { WBD } \\
\left(\mathrm{g} / \mathrm{cm}^{3}\right)\end{array}$ & $\begin{array}{c}\text { DBD } \\
\left(\mathrm{g} / \mathrm{cm}^{3}\right)\end{array}$ \\
\hline $1-1$ & 7.7 & 1.242 & 0.35 \\
$1-1$ & 23.0 & 1.310 & 0.46 \\
$1-1$ & 38.4 & 1.266 & 0.39 \\
$1-1$ & 53.7 & 1.299 & 0.45 \\
$1-1$ & 69.1 & 1.344 & 0.52 \\
$1-1$ & 84.4 & 1.330 & 0.50 \\
$1-1$ & 99.7 & 1.253 & 0.37 \\
$1-1$ & 115.1 & 1.200 & 0.28 \\
$1-1$ & 130.4 & 1.213 & 0.30 \\
$1-1$ & 145.8 & 1.280 & 0.41 \\
$1-2$ & 188.4 & 1.259 & 0.38 \\
$1-2$ & 203.7 & 1.222 & 0.32 \\
$1-2$ & 219.1 & 1.271 & 0.40 \\
$1-2$ & 234.4 & 1.288 & 0.43 \\
$1-2$ & 249.7 & 1.291 & 0.43 \\
$1-2$ & 265.1 & 1.237 & 0.34 \\
$1-2$ & 280.4 & 1.234 & 0.34 \\
$1-2$ & 295.8 & 1.202 & 0.28 \\
$2-1$ & 287.7 & 1.178 & 0.24 \\
$2-1$ & 303.0 & 1.207 & 0.29 \\
$2-1$ & 318.4 & 1.257 & 0.38 \\
$2-1$ & 333.7 & 1.321 & 0.48 \\
$2-1$ & 349.1 & 1.291 & 0.43 \\
$2-1$ & 364.4 & 1.265 & 0.39 \\
$2-1$ & 379.7 & 1.213 & 0.30 \\
$2-1$ & 395.1 & 1.186 & 0.26 \\
$2-1$ & 410.4 & 1.190 & 0.26 \\
$2-1$ & 425.8 & 1.284 & 0.42 \\
$2-2$ & 453.0 & 1.408 & 0.63 \\
$2-2$ & 468.4 & 1.361 & 0.55 \\
$2-2$ & 483.7 & 1.388 & 0.59 \\
$2-2$ & 499.1 & 1.379 & 0.58 \\
$2-2$ & 514.4 & 1.309 & 0.46 \\
$2-2$ & 529.7 & 1.203 & 0.29 \\
$2-2$ & 545.1 & 1.194 & 0.27 \\
$2-2$ & 560.4 & 1.293 & 0.44 \\
$2-2$ & 575.8 & 1.312 & 0.47 \\
\hline & & & \\
& & & \\
2 & & &
\end{tabular}

Note: Dry-bulk density calculated from wet-bulk density data of Mayer (this volume) by the relation $\mathrm{DBD}=1.656 \times \mathrm{WBD}-1.706$.

this represents a factor of nearly 3.1 range in grain mass. Positions of the grain-size maxima along the core do not correspond to times of glacial maxima-as was anticipated at the outset. Rather, ten peaks in eolian grain size occur, which show no apparent correspondence to the glacial-interglacial cycles recorded in the carbonate data (Fig. 1). These ten maxima span an age range of $422,300 \mathrm{y}$. (sample ages from Table 4), suggesting that tradewind intensity is controlled by the 42,000-y. cycle in obliquity of the Earth's axis (Hays et al., 1976).

The change in grain size can be used to quantify the relative change in wind strength. The calculation is based on the assumption that, far from their source, eolian grains have a size distribution in equilibrium with average wind intensity (Windom, 1975; Johnson, 1976; Schütz, 1979); the settling velocity of the equilibrium grains is balanced by the lifting effect of atmospheric motions. Changes in wind intensity can then be determined by comparing, in a ratio, the settling velocities of the different-size particles. In such a ratio, the signifi- cant terms are the square of the two particle diameters; other terms cancel out. Thus the ratio of high-to-low wind intensities, $R_{w}$, is the ratio of the squares of the grain sizes $D_{H}^{2}$ and $D_{L}^{2}: R_{w}=D_{H}^{2} / D_{L}^{2}$. Wind-intensity ratios can be calculated for every change in grain size, resulting in an average $R_{w}$ of $1.36 \pm 0.22$ with extremes of 1.07 and 1.94. This value is a measure of the increase in tradewind vigor from times of reduced to times of increased circulation and agrees reasonably well with estimates from different data made by Gates (1976) and Molina-Cruz (1977).

\section{DISCUSSION}

\section{Cycles of Eolian Sedimentation}

The expected cyclicity of the eolian contributions to the deep ocean with changes in global climate is confirmed by the data already presented. The amount of that contribution over the long term (millions of years; Rea and Janecek, 1980, in press b) and shorter term (tens of thousands of years) appears to depend more on the aridity of the source area than on wind strength (Fig. 1). Under more humid conditions, less dust can be entrained in the atmosphere. Hole 503B records indicate a reduced eolian contribution during glacial times-an apparent consequence of greater humidity and vegetative cover in Central America and northwestern South America during glaciations. Times of maximum eolian MAR correspond approximately to, or are somewhat younger than, the carbonate-data indicators of glacial terminations as already defined (Fig. 1). Thus these maxima occur perhaps $10,000 \mathrm{y}$. after the large reductions in ice volume recorded by $\delta^{18} \mathrm{O}$ data. As interglacial periods may last tens of thousands of years (Hays et al., 1976), the data suggests that, within the eolian source regions, the earlier portions of interglacial periods may be more arid than the latter portions.

The grain size-wind vigor appears to reflect the $42,000-y$. periodicity of the tilt of the earth's axis. The earth's tilt determines, to a large extent, the distribution of incoming solar radiation, which would be expected to influence latitudinal temperature gradients and, thus, wind intensity. Because ocean-surface circulation responds to the atmosphere, the 42,000 -y. cycle might be expected to occur in phenomena (e.g., coastal and oceanic upwelling and resulting biological productivity) related to surface circulation. Such cycles may occur in central Atlantic pelagic sediments throughout the middle and late Cenozoic (Dean et al., 1981).

\section{SUMMARY}

Sediment in the first two hydraulic piston cores raised from Hole 503B in the eastern equatorial Pacific contains a clear carbonate-preservation record of the last five glacial stages. We have isolated the wind-borne component of those pelagic sediments and determined its MAR. The results show that the eolian contribution to the eastern equatorial Pacific is lower, by a factor of three to five, during glacial times than during interglacials. Mass-accumulation-rate values of 24 to $80 \mathrm{mg}$ / 
Table 4. Weight percentage, accumulation rate, and size of eolian materials, Hole 503B.

\begin{tabular}{|c|c|c|c|c|c|c|c|c|c|c|}
\hline $\begin{array}{l}\text { Core/ } \\
\text { Section } \\
\text { (interval } \\
\text { in } \mathrm{cm} \text { ) }\end{array}$ & $\begin{array}{l}\text { Sub-bottom } \\
\text { Depth } \\
\text { (cm) }\end{array}$ & $\begin{array}{l}\mathrm{CaCO}_{3} \mathrm{a} \\
(w \mathrm{t} . \%)\end{array}$ & $\begin{array}{l}\text { Eolian } \\
\text { Material } \\
\text { (wt. \%) }\end{array}$ & $\begin{array}{c}\mathrm{CaCO}_{3} \text {-Free } \\
\text { Eolianb } \\
\text { (wt. \%) }\end{array}$ & $\begin{array}{c}\mathrm{DBD}^{\mathrm{c}} \\
\left(\mathrm{g} / \mathrm{cm}^{3}\right)\end{array}$ & $\begin{array}{c}\text { LSR } \\
\left(\mathrm{cm} / 10^{3} \mathrm{y} .\right)\end{array}$ & $\begin{array}{c}\text { Total MAR } \\
\left(\mathrm{g} / \mathrm{cm}^{2} / 10^{3} \mathrm{y}_{.}\right)\end{array}$ & $\begin{array}{c}\text { Eolian MAR } \\
\left(\mathrm{mg} / \mathrm{cm}^{2} / 10^{3} \mathrm{y} .\right)\end{array}$ & $\begin{array}{c}\text { Eolian } \\
\text { Size } \\
\left(\phi_{50}\right)\end{array}$ & $\begin{array}{c}\text { Sample } \\
\text { Aged } \\
\left(10^{3} \text { y.) }\right.\end{array}$ \\
\hline $1-1,4-6$ & 005.0 & 55.0 & 5.49 & 12.2 & 0.33 & 1.34 & 0.44 & 24.0 & 8.54 & 003.7 \\
\hline $1-1,16-18$ & 017.0 & 62.0 & 4.69 & 12.3 & 0.42 & 1.34 & 0.56 & 26.0 & 8.56 & 012.7 \\
\hline $1-1,34-36$ & 035.0 & 68.0 & 5.48 & 17.1 & 0.41 & 1.34 & 0.55 & 30.0 & 8.51 & 026.1 \\
\hline $1-1,48-50$ & 049.0 & 72.0 & 6.86 & 24.5 & 0.42 & 1.34 & 0.56 & 38.0 & 8.51 & 036.6 \\
\hline $1-1,57-59$ & 058.0 & 74.0 & 5.90 & 22.7 & 0.47 & 1.34 & 0.63 & 37.0 & 8.66 & 043.3 \\
\hline $1-1,68-70$ & 069.0 & 75.0 & 7.83 & 31.3 & 0.52 & 1.34 & 0.70 & 55.0 & 8.68 & 051.5 \\
\hline $1-1,84-86$ & 085.0 & 70.0 & 4.73 & 15.8 & 0.49 & 1.34 & 0.66 & 31.0 & 8.50 & 063.4 \\
\hline $1-1,98-100$ & 099.0 & 40.0 & 17.60 & 29.3 & 0.37 & 1.34 & 0.50 & 88.0 & 8.46 & 073.9 \\
\hline $1-1,107-109$ & 108.0 & 35.0 & 12.85 & 19.8 & 0.32 & 1.34 & 0.43 & 55.0 & 8.48 & 080.6 \\
\hline $1-1,118-120$ & 119.0 & 31.0 & 25.71 & 37.3 & 0.28 & 1.34 & 0.38 & 98.0 & 8.52 & 088.8 \\
\hline $1-1,128-130$ & 129.0 & 32.5 & 28.12 & 41.7 & 0.30 & 1.34 & 0.40 & 112.0 & 8.57 & 093.6 \\
\hline $1-1,143-145$ & 144.0 & 33.5 & 15.79 & 23.7 & 0.40 & 1.34 & 0.54 & 85.0 & 8.42 & 107.5 \\
\hline $1-2,12-14$ & 161.0 & 41.0 & 21.72 & 36.8 & 0.40 & 1.34 & 0.54 & 117.0 & 8.57 & 120.1 \\
\hline $1-2,26-28$ & 175.0 & 55.0 & 16.10 & 35.8 & 0.38 & 1.28 & 0.49 & 79.0 & 8.72 & 131.1 \\
\hline $1-2,37-39$ & 186.0 & 65.0 & 11.04 & 31.5 & 0.38 & 1.28 & 0.49 & 54.0 & 8.57 & 139.7 \\
\hline $1-2,46-48$ & 195.0 & 68.5 & 11.18 & 35.5 & 0.34 & 1.28 & 0.44 & 49.0 & 8.66 & 146.8 \\
\hline $1-2,57-59$ & 206.0 & 65.6 & 12.20 & 35.4 & 0.35 & 1.28 & 0.45 & 55.0 & 8.66 & 155.3 \\
\hline $1-2,76-78$ & 225.0 & 54.0 & 15.87 & 34.5 & 0.42 & 1.28 & 0.54 & 86.0 & 8.78 & 170.2 \\
\hline $1-2,94-96$ & 243.0 & 49.0 & 9.14 & 17.9 & 0.43 & 1.28 & 0.55 & 50.0 & 8.74 & 184.2 \\
\hline $1, \mathrm{CC}(9-11)$ & 264.0 & 51.0 & 14.10 & 28.8 & 0.35 & 1.28 & 0.45 & 63.0 & 8.71 & 200.7 \\
\hline $2-1,1-3$ & 282.0 & 53.0 & 14.97 & 31.9 & 0.33 & 1.28 & 0.42 & 63.0 & 8.60 & 214.7 \\
\hline $2-1,17-19$ & 298.0 & 47.0 & 18.36 & 34.6 & 0.29 & 1.28 & 0.37 & 68.0 & 8.66 & 227.2 \\
\hline $2-1,37-39$ & 318.0 & 39.0 & 27.17 & 44.5 & 0.38 & 1.28 & 0.49 & 133.0 & 8.49 & 242.8 \\
\hline $2-1,47-49$ & 328.0 & 47.0 & 29.14 & 55.0 & 0.45 & 1.28 & 0.58 & 169.0 & 8.36 & 250.7 \\
\hline $2-1,63-65$ & 344.0 & 68.0 & 6.93 & 21.7 & 0.45 & 0.96 & 0.43 & 30.0 & 8.43 & 265.6 \\
\hline $2-1,79-81$ & 360.0 & 65.5 & 12.45 & 36.1 & 0.40 & 0.96 & 0.38 & 47.0 & 8.25 & 282.2 \\
\hline $2-1,95-97$ & 376.0 & 48.5 & 16.27 & 31.6 & 0.32 & 0.96 & 0.31 & 50.0 & 8.67 & 298.9 \\
\hline $2-1,111-113$ & 392.0 & 41.5 & 17.99 & 30.8 & 0.27 & 0.96 & 0.26 & 47.0 & 8.73 & 315.6 \\
\hline $2-1,127-129$ & 408.0 & 40.5 & 17.26 & 29.0 & 0.26 & 0.96 & 0.25 & 43.0 & 8.64 & 332.2 \\
\hline $2-1,143-145$ & 424.0 & 63.0 & 16.93 & 45.8 & 0.40 & 1.18 & 0.47 & 80.0 & 8.46 & 348.7 \\
\hline $2-2,10-12$ & 440.0 & 75.0 & 4.12 & 16.5 & 0.53 & 1.18 & 0.63 & 26.0 & 8.41 & 362.3 \\
\hline $2-2,25-27$ & 455.0 & 78.5 & 6.91 & 32.1 & 0.62 & 1.18 & 0.73 & 50.0 & 8.58 & 375.0 \\
\hline $2-2,40-42$ & 470.0 & 77.5 & 7.60 & 33.8 & 0.56 & 1.18 & 0.66 & 50.0 & 8.79 & 387.7 \\
\hline $2-2,48-50$ & 478.0 & 75.0 & 8.07 & 32.3 & 0.57 & 1.18 & 0.67 & 54.0 & 8.68 & 394.5 \\
\hline $2-2,63-65$ & 493.0 & 64.5 & 6.65 & 18.7 & 0.58 & 1.18 & 0.68 & 45.0 & 8.48 & 407.2 \\
\hline $2-2,78-80$ & 508.0 & 47.0 & 22.56 & 42.6 & 0.50 & 1.18 & 0.59 & 133.0 & 8.65 & 419.9 \\
\hline $2-2,88-90$ & 518.0 & 30.0 & 26.84 & 38.3 & 0.41 & 1.18 & 0.48 & 129.0 & 8.64 & 428.4 \\
\hline $2-2,98-100$ & 528.0 & 46.0 & 24.01 & 44.5 & 0.29 & 1.18 & 0.34 & 82.0 & 8.65 & 436.8 \\
\hline $2 \cdot 2,113-115$ & 543.0 & 64.5 & 8.24 & 23.2 & 0.27 & 1.18 & 0.32 & 26.0 & 8.53 & 449.5 \\
\hline $2-2,124-126$ & 554.0 & 70.0 & 6.00 & 20.0 & 0.37 & 1.18 & 0.44 & 26.0 & 8.38 & 453.9 \\
\hline
\end{tabular}

${ }^{a} \mathrm{CaCO}_{3}$ values interpolated from data in Table 1.

b Calculated wt. \% eolian $/ 1.00-\% \mathrm{CaCO}_{3}$.

c Interpolated from DBD values in Table 3.

$\mathrm{d}$ Interpolated from age and LSR values in Table 2.

$\mathrm{cm}^{2} / 10^{3} \mathrm{y}$. coincide with carbonate maxima; values of 86 to $169 \mathrm{mg} / \mathrm{cm}^{2} / 10^{3} \mathrm{y}$. generally coincide with low carbonate values. Lower contributions during glaciations may occur, because the eolian source area, Central America and northwestern South America, was more humid, and the increased vegetative cover prevented entrainment of dust into the atmosphere.

At some distance downwind from the source, perhaps 1000 or $2000 \mathrm{~km}$ (Windom, 1975; Johnson, 1976; Schütz, 1979), the grain size of eolian material is in equilibrium with the vigor of the transporting wind. As a result, at any one location the size of the eolian grains provides a history of wind vigor. In Hole 503B, the largest eolian grains occur in ten maxima spaced over about 422,000 y., suggesting that the $42,000-y$. cycle in tilt of the earth's spin axis determines the relative intensity of the trade winds. Since wind intensity affects the vigor of oceanic surface circulation, the same 42,000-y. cycle might be expected in upwelling or productivity records.

\section{ACKNOWLEDGMENTS}

I would like to thank Jim Gardner for providing samples from Hole 503B for our research. He and Larry Mayer provided their carbonate and bulk-density data readily and rapidly on request; this report could not have been completed otherwise. Tom Janecek performed the laboratory analyses with his usual skill and care. The manuscript received careful reviews from Reginald E. Newell and Margaret Leinen; Jim Gardner and Perry Samson read and commented on earlier versions of the manuscript. Their efforts are appreciated. Funding for this work has been provided by the National Science Foundation through Grants OCE7825341 and OCE8024368.

\section{REFERENCES}

Arrhenius, G., 1952. Sediment cores from the east Pacific , Pt. 1. In Pettersson, H. (Ed.), Reports of the Swedish Deep-Sea Expedition 1947-1948 (Vol. 5): Goteborg (Elanders).

Bowler, J. M., Hope, G. S., Jennings, J. N., Singh, G., and Walker, D., 1976. Late Quaternary climates of Australia and New Guinea. Quat. Res., 6:359-394.

Brakenridge, G. R., 1978. Evidence for a cold, dry, full-glacial climate in the American southwest. Quat. Res., 9:22-40.

Butzer, K. W., Isaac, G. L., Richardson, J. L., and WashbournKamau, C., 1972. Radiocarbon dating of East African lake levels. Science, 175:1069-1076. 
CLIMAP Project Members, 1976. The surface of the ice-age earth. Science, 191:123-137.

Dean, W. E., Gardner, J. V., and Čepek, P., 1981. Tertiary carbonatedissolution cycles on the Sierra Leone Rise, eastern Equatorial Atlantic Ocean. Mar. Geol., 39:81 101.

Diester-Haass, L., 1976. Late Quaternary climatic variations in Northwest Africa deduced from East Atlantic sediment cores. Quat. Res., 6:299-314.

Folk, R. L., 1974. Petrology of Sedimentary Rocks: Austin, Tex. (Hempthill).

Frenzel, B., 1973. Climatic Fluctuations of the Ice Age: Cleveland (Case Western Reserve Press).

Gates, W. L., 1976. Modeling the ice-age climate. Science, 191:11381144.

Hays, J. D., Imbrie, J., and Shackleton, N. J., 1976. Variations in the earth's orbit: Pacemaker of the Ice Ages. Science, 194:11211132.

Hays, J. D., Saito, T., Opdyke, N. D., and Burckle, L. H., 1969. Pleistocene-Pliocene sediments of the Equatorial Pacific: Their paleomagnetic, biostratigraphic, and climatic record. Geol. Soc. Am. Bull., 80:1481-1514.

Janecek, T. R., Rea, D. K., Pisias, N. G., and Leinen, M., 1980. Cenozoic eolian input to the Northeastern Pacific Ocean, data from core LL-44-GPC-3. Geol. Soc. Am. Abstract with Programs, 12:455. (Abstract)

Johnson, L. R., 1976. Particle-size fractionation of eolian dusts during transport and sampling. Mar. Geol., 21:M17-M21.

1979. Mineralogical dispersal patterns of North Atlantic deep-sea sediments with particular reference to eolian dusts. Mar. Geol., 29:334-345.

Kershaw, A. P., 1978. Record of last interglacial-glacial cycle from northeastern Queensland. Nature, 272:159-161.

Lamb, H. H., 1977. Climate Past, Present, and Future, Volume 2, Climatic History and the Future: London (Methuen).

Leinen, M., 1979. Biogenic silica sedimentation in the equatorial $\mathrm{Pa}$ cific during the Cenozoic and its implications for paleoceanography. Geol. Soc. Am. Bull., 90:1310-1376.

Leinen, M., and Heath, G. R., in press. Sedimentary indicators of atmospheric circulation in the Northern Hemisphere during the Cenozoic. Palaeogeog. Palaeoclimatol. Palaeoecol.

Lisitzin, A. P., 1972. Sedimentation in the World Ocean. Society of Economic Paleontologists and Mineralogists, Special Publication 17: Tulsa (Society of Economic Paleontologists and Mineralogists).

Manabe, S., and Hahn, D. G., 1977. Simulation of the tropical climate of an ice age. J. Geophys. Res., 82:3889-3911.

Mikkelsen, N., 1978. Preservation of diatoms in glacial to Holocene deep-sea sediments of the equatorial Pacific. Geology, 6:553-555.

Molina-Cruz, A., 1975. Paleo-oceanography of the subtropical southeastern Pacific during late Quaternary: A study of Radiolaria, opal and quartz contents of deep-sea sediments [M.S. thesis]. Oregon State University.

1977. The relation of the southern trade winds to upwelling processes during the last 75,000 years. Quat. Res., 8:324-339.

Molina-Cruz, A., and Price, P., 1977. Distribution of opal and quartz on the ocean floor of the subtropical southeastern Pacific. Geology, 5:81-84.

Moore, T. C., Jr., Burckle, L. H., Geitzenauer, K., Luz, B., MolinaCruz, A., Robertson, J. H., Sachs, H., Sancetta, C., Thiede, J., Thompson, P., and Wenkam, C., 1980. The reconstruction of seasurface temperatures in the Pacific Ocean of 18,000 B.P. Mar. Micropaleontol., 5:215-247.

Moore, T. C., Jr., Pisias, N. G., and Heath, G. R., 1977. Climate changes and lags in Pacific carbonate preservation, sea-surface temperature, and global ice volume. In Anderson, N. R., and Malahoff, A. (Eds.), The Fate of Fossil Fuel $\mathrm{CO}_{2}$ in the Oceans: New York (Plenum), pp. 145-165.

Ninkovich, D., and Shackleton, N. J., 1975. Distribution, stratigraphic position, and age of ash layer " $L$ " in the Panama Basin region. Earth Planet. Sci. Lett., 27:20-34.

Parkin, D. W., 1974. Trade winds during the glacial cycles. Proc. $R$. Soc. London Ser. A, 337:73-100.

Parkin, D. W., and Padgham, R. C., 1975. Further studies on trade winds during the glacial cycles. Proc. R. Soc. London Ser. A, 346: $345-360$.
Parkin, D. W., and Shackleton, N. J., 1973. Trade winds and temperature correlations down a deep sea core off the Saharan coast. $\mathrm{Na}$ ture, 245:455-457.

Peterson, G. M., Webb, T., III, Kutzbach, J. E., van der Hammen, T., Wijmstra, T. A., and Street, F. A., 1979. The continental record of environmental conditions at 18,000 yr B.P.: An initial evaluation. Quat. Res., 12:47-82.

Pisias, N. G., 1976. Late Quaternary variations in sedimentation rate in the Panama Basin and the identification of orbital frequencies in carbonate and opal deposition rates. In Cline, R. M., and Hays, J. D. (Eds.), Investigation of Late Quaternary Paleoceanography and Paleoclimatology: Geological Society of America Memoir 145: Boulder (Geological Society of America), 375-391.

Prospero, J. M., and Bonatti, E., 1969. Continental dust in the atmosphere of the eastern equatorial Pacific. J. Geophys. Res., 74: 3362-3371.

Prospero, J. M., Glaccum, R. A., and Nees, R. T., 1981. Atmospheric transport of soil dust from Africa to South America. Nature, 289: 570-572.

Rea, D. K., and Harrsch, E. C., in press. Mass accumulation rates of the non-authigenic, inorganic, crystalline (eolian) component of deep-sea sediments from the Hess Rise, DSDP Sites 464, 465, and 466. In Thiede, J., T. L. Vallier, et al., Init. Repts. DSDP, 62: Washington (U.S. Govt. Printing Office).

Rea, D. K., and Janecek, T. R., 1980. Grain size and accumulation rate of the eolian component of some North Pacific sediments. Trans. Am. Geophys. Union, 61:257. (Abstract)

in press a. Mass accumulation rates of the non-authigenic, inorganic, crystalline (eolian) component of deep-sea sediments from the western mid-Pacific mountains, DSDP Site 463. In Thiede, J., T. L. Vallier, et al., Init. Repts. DSDP, 62: Washington (U.S. Govt. Printing Office).

in press b. Late Cretaceous history of eolian deposition in the Mid-Pacific Mountains, central North Pacific Ocean. Palaeogeog. Palaeoclimatol. Palaeoecol.

Rex, R. W., and Goldberg, E. D., 1958. Quartz contents of pelagic sediments of the Pacific Ocean. Tellus, 10:153-159.

Sarnthein, 1978. Sand deserts during glacial maximum and climatic optimum. Nature, 272:43-46.

Savoie, D. L., and Prospero, J. M., 1980. Water-soluble potassium, calcium, and magnesium in aerosols over the tropical North Atlantic. J. Geophys. Res., 85:385-392.

Schütz, L., 1979. Sahara dust transport over the North Atlantic Oceanmodel calculations and measurements. In Morales, C. (Ed.), Saharan Dust Mobilization Transport Deposition: New York (John Wiley), pp. 267-277.

Shackleton, N. J., and Opdyke, N. D., 1973. Oxygen isotope and paleomagnetic stratigraphy of equatorial Pacific core V28-238: Oxygen isotope temperatures and ice volumes on a $10^{5}$ and $10^{6}$ year scale. Quat. Res., 3:39-55.

1976. Oxygen isotope and paleomagnetic stratigraphy of Pacific core V28-239, Late Pliocene to latest Pleistocene. In Cline, R. M., and Hays, J. D. (Eds.), Investigations of Late Quaternary Paleoceanography and Paleoclimatology. Geological Society of American Memoir 145: Boulder (Geological Society of America), 449-464.

Street, F. A., and Grove, A. T., 1979. Global maps of lake-level fluctuations since 30,000 yr B.P. Quat. Res., 12:83-118.

Thiede, J., 1979. Wind regimes over the Late Quaternary southwest Pacific Ocean. Geology, 7:259-262.

Thompson, P. R., and Saito, T., 1974. Pacific Pleistocene sediments: Planktonic foraminifera dissolution cycles and geochronology. Geology, 2:333-335.

Webster, P. J., and Streten, N. A., 1978. Late Quaternary ice age climates of tropical Australasia: Interpretations and reconstructions. Quat. Res., 10:279-309.

Williams, M. A. J., 1975. Late Pleistocene tropical aridity synchronous in both hemispheres? Nature, 253:617-618.

Windom, H. L., 1969. Atmospheric dust records in permanent snow fields: Implications to marine sedimentation. Geol. Soc. Am. Bull., 80:761-782.

1975. Eolian contributions to marine sediments. J. Sediment. Petrol., 45:520-529. 